\title{
Impact of minimum support price scheme for groundnut on farm incomes in North Karnataka
}

\author{
K.N. ASHARANI, C. MURTHY AND M.S. KISHORE
}

Received : 10.08.2016; Revised : 26.08.2016; Accepted : 13.09.2016

\begin{abstract}
MSP is a form of market intervention by the Government of India to insure agricultural producers against any sharp fall in farm prices to protect the producer- farmers- against excessive fall in price during bumper production years. The effectiveness of price policy at the state level involves the availability of market infrastructure at the state level and the initiative taken by the State Governments to create an institutional structure for monitoring agricultural prices. The study was conducted during the year 2015-16 using the secondary data pertaining to the MSP for different crops and open market prices for groundnut in selected market of Gadag district. Compound growth rate were computed to comprehend the annual growth in MSP of agricultural commodities for the period from 2000-01 to 2015-16. It is revealed that the annual growth rate for MSP for all commodities was found to be positive. The growth rate of MSP for groundnut was 9.26 per cent. The increase in MSP was not equitable to all the crops. Both open market prices and MSP shown increasing trend but most of the years, open market prices for groundnut were higher than the MSP in all the selected market of Gadag and the percentage differences were not high. The influence of MSP on market price was not significant in groundnut. Hence, there is need to bring some improvement in the price policy to different crops in ensuring highest returns to the farmers to continue their production with the increase in cost of inputs especially the crop groundnut.
\end{abstract}

KEY WORDS : Minimum support prices, Groundnut, Gadag, Compound growth rate

How to cite this paper : Asharani, K.N., Murthy, C. and Kishore, M.S. (2016). Impact of minimum support price scheme for groundnut on farm incomes in North Karnataka. Internat. J. Com. \& Bus. Manage, 9(2) : 202-208. DOI: 10.15740/HAS/IJCBM/9.2/202-208.

\section{MEMBERS OF THE RESEARCH FORUM}

Correspondence to:

K.N. ASHARANI, Department of Agribusiness Management, College of Agriculture, University of Agricultural Sciences, DHARWAD (KARNATAKA) INDIA

Email: asharanikn3@gmail.com

\section{Authors' affiliations:}

C. MURTHY AND M.S. KISHORE, Department of Agribusiness Management, College of Agriculture, University of Agricultural Sciences, DHARWAD (KARNATAKA) INDIA

Email: cmurthy1966@gmail.com ; nabuta127@gmail.com 